\title{
Neolithisation of technology: innovation and tradition in the Starčevo culture osseous industry
}

\author{
Selena Vitezović \\ Institute of Archaeology, Belgrade, SRB \\ selenavitezovic@gmail.com; s.vitezovic@ai.ac.rs
}

\begin{abstract}
The earliest Neolithic cultures in Southeast Europe brought significant changes in many aspects of everyday life, in subsistence, settlement patterns, architecture, and also ritual aspects. Technological changes are also very important - the introduction of completely new technologies, such as clay working, or new techniques in existing industries, e.g., lithic, osseous, etc. The osseous industry is especially informative for questions on innovations and traditions, since it was well developed in both the Mesolithic and Neolithic periods. In Starčevo culture, certain Mesolithic traditions may be observed, such as techniques for antler manufacture; however, numerous innovations are also visible, particularly techno-types of Near Eastern origin such as spatula-spoons, the most characteristic bone techno-type of the Early Neolithic in South-east Europe, as well as diverse decorative items. Furthermore, new raw materials (bones from domestic animals) are introduced, and new techniques for manufacture and new tools. It is also interesting to observe that, although osseous materials remain the dominant raw material for personal ornaments, they are no longer used for artistic expression.
\end{abstract}

IZVLEČEK - Najstarejše neolitske kulture jugovzhodne Evrope so prinesle bistvene spremembe v aspektih vsakodnevnega življenja, v gospodarstvo, poselitvene vzorce, arhitekturo, pa tudi v ritualne vidike življenja. Tehnološke spremembe so prav tako pomembne - uvajanje povsem novih tehnologij kot je obdelava gline ali vpeljava novih tehnik v obstoječe tehnologije obdelave npr. kamna, kosti itd. Predvsem obdelava kosti je izpovedna pri vprašanjih, ki so vezana na inovacije in tradicije, saj je dobro razvita tako v mezolitiku kot v neolitiku. V kulturi Starčevo lahko tako opazujemo nekatere mezolitske tradicije, kot je obdelava rogovja; kljub temu pa prepoznamo tudi številne inovacije, predvsem pri tehnoloških tipih, ki imajo izvor na Bližnjem vzhodu kot so žlice, najbolj značilen tip v zgodnjem neolitiku jugovzhodne Evrope, isto pa velja za raznorazne dekorativne izdelke. Značilna pa je tudi uporaba novih vrst surovin (kosti domačih živali) in uporaba novih tehnik obdelave in izdelava novih orodij. Zanimivo je, da izdelki iz kosti ne predstavljajo več umetniško izražanje, čeprav ostaja kost poglavitna surovina za izdelavo osebnih izdelkov oz. okraskov.

KEY WORDS - osseous raw materials; technological choices; technological innovations; StarčevoKörös-Criş culture

\section{Introduction}

Although often considered as being completely determined by environmental constraints and ergonomic factors, technology is actually a social phenomenon closely linked with diverse social, cultural and economic aspects (cf. Lemonnier 1992; 1993; see also Killick 2004). According to Pierre Lemonnier (1992), the study of technology should not be limited to its effects on society; technologies must be considered in a general anthropological perspective as social productions that are determined by, and compatible with, other social phenomena. Technologies must not be seen only as constraints; the social aspect of material culture must also be taken into consideration (Lemonnier 1992; 1993; Pfaffenberger 1992).

An important characteristic of all technologies is their systemic aspect. Every technique has five relat- 
ed components: matter, the material on which technique acts; energy, i.e. the forces which move objects and transform matter, tools or means of work; gestures, which move the objects involved in a technological action, and, finally, specific knowledge, which may be conscious or unconscious. Furthermore, all these techniques form a system, and, within this system, multiple interactions exist between the tools, the material that is being transformed, the actions and the knowledge needed to transformation it. All these elements are interdependent; diverse techniques in a given society can share the same resources, the same knowledge, the same tools and the same actors. One technique may use the products of the others; techniques may share operational sequences or technical principles. This creates multiple relations of interdependence among them; variations in any of the five technical elements causes changes in others, and any alteration within one technology influences modifications in others (cf. Lemonnier 1986; 1992).

In terms of the meaning and importance of some technology within a given society, we may group them into practical and prestigious ones ( $c f$. Hayden 1998). Practical technologies are used to solve practical problems of survival and basic comfort, such as providing food or shelter, and their most important principle is to perform required tasks in an efficient and effective way. However, there are different kinds of constraints operating in the development of solutions for each problem, such as functional requirements, material properties, availability, and production costs. It is unlikely, therefore, that there will be a single optimal solution for every problem. The criteria used in choosing between alternative technological solutions are how effective and how costly each solution is, but also the choice of the solution that is adopted may largely depend on culture tradition, ideological values, style, etc. (Hayden 1998).

Prestigious technologies, on the other hand, display power, wealth, prestige, success. Prestigious artefacts are not created to perform a practical, but a social, task, and they play a key active role in the acquisition of status and power. The purpose is to solve a social problem or to accomplish a social task, such as attracting allies, or bonding members of social groups together. Therefore, the logic and strategy for creating prestige artefacts are fundamentally different from the logic and strategy for creating practical ones. Prestige technologies employ as much surplus labour as possible to create objects that will attract and draw attention, status and prestige to the owner (Hayden 1998). Analysing the appearance and development of prestigious technologies among hunter-gatherer communities, Brian Hayden (1998. 17-18) also argued that many, perhaps even all, of the technological achievements were initially developed as prestige technologies and only later evolved into more practical applications such as pottery, metalworking, domestication of plants and animals, etc.

Not only are technological choices influenced, even directed, by cultural and social phenomena, but specific technological traits may be cultural and chronological markers, and the technology itself may be used to display identity, status and/or prestige, to emphasise group identity, for example (e.g., Wake 1999). Even a skill itself may be valued (cf. Sinclair 1995; 1998), and it may have been used to display or increase the prestigious status of the artisan who produced certain skill-demanding items.

\section{The archaeological background}

The Early Holocene in the central Balkan area is marked by a specific Mesolithic culture, labelled after the eponymous sites Lepenski Vir or Lepenski Vir-Schela Cladovei culture. All the sites were discovered in the Iron Gates region, part of the Danube valley and present-day border between Serbia and Romania: Lepenski Vir, Vlasac, Padina, Hajdučka Vodenica and Kula on the Serbian side of the Danube, and on the Romanian side sites at Alibeg, Cuina Turcului, Icoana, Ostrovul Banului, Ostrovul Corbului, Răzvrata, Schela Cladovei, Ostrovul Mare, etc. (Bonsall 2008; Borić 2002; Boroneant 1970; 2000; Radovanovic 1996). Absolute dates for the Lepenski Vir site show that the earliest Mesolithic occupation began around $9400 \mathrm{cal} \mathrm{BC}$, while the trapezoidal houses had been abandoned by around $5900 \mathrm{cal} \mathrm{BC}$ (Borić, Dimitrijević 2007; for more dates see also Bonsall 2008 and references therein).

Whether these communities were mobile or sedentary is still a subject of research; a certain level of sedentarism, however, may be observed. These communities practiced hunting of the game abundant in the forests in the area, and also fishing, in particular fishing for large migratory fish (Bökönyi 1978; Bartosiewicz et al. 2008; Clason 1982; Dimitrijević 2008; Dinu 2010).

A very peculiar material culture is the hallmark for the Iron Gates Mesolithic, with spectacular non-utilitarian items, which included ornamented stones discovered at several sites, and even sculptures 
placed within trapezoidal structures at the Lepenski Vir site. Also, rich and diverse lithic and bone industries were uncovered ( $c f$. Antonović 2006; Bačkalov 1979; Beldiman 2007; Radovanović 1981; 1996; Vitezović 2011b).

The Early Neolithic introduced numerous innovations - not only farming and animal husbandry, new plant and animal species, but also changes in ways of life and worldviews (cf. Hodder 1990; Cauvin 1997). The earliest Neolithic communities in the central Balkan region were part of the Starčevo-KörösCriș cultural complex (for absolute dates, $c f$. Whittle et al. 2002). The Neolithic settlers were a new population in the region; however, the nature of their relations with the Mesolithic communities is still not entirely clear (cf. Bonsall 2008.267-278).

Starčevo communities were agricultural; they practised farming and animal herding, although hunting and gathering also played a certain role in subsistence (cf. Filipović, Obradović 2013; Clason 1982; Greenfield 2008). Settlements consisted of semidugout pit-dwellings and huts above ground made from wattle and daub. Their material culture brought in numerous innovations, the most important and

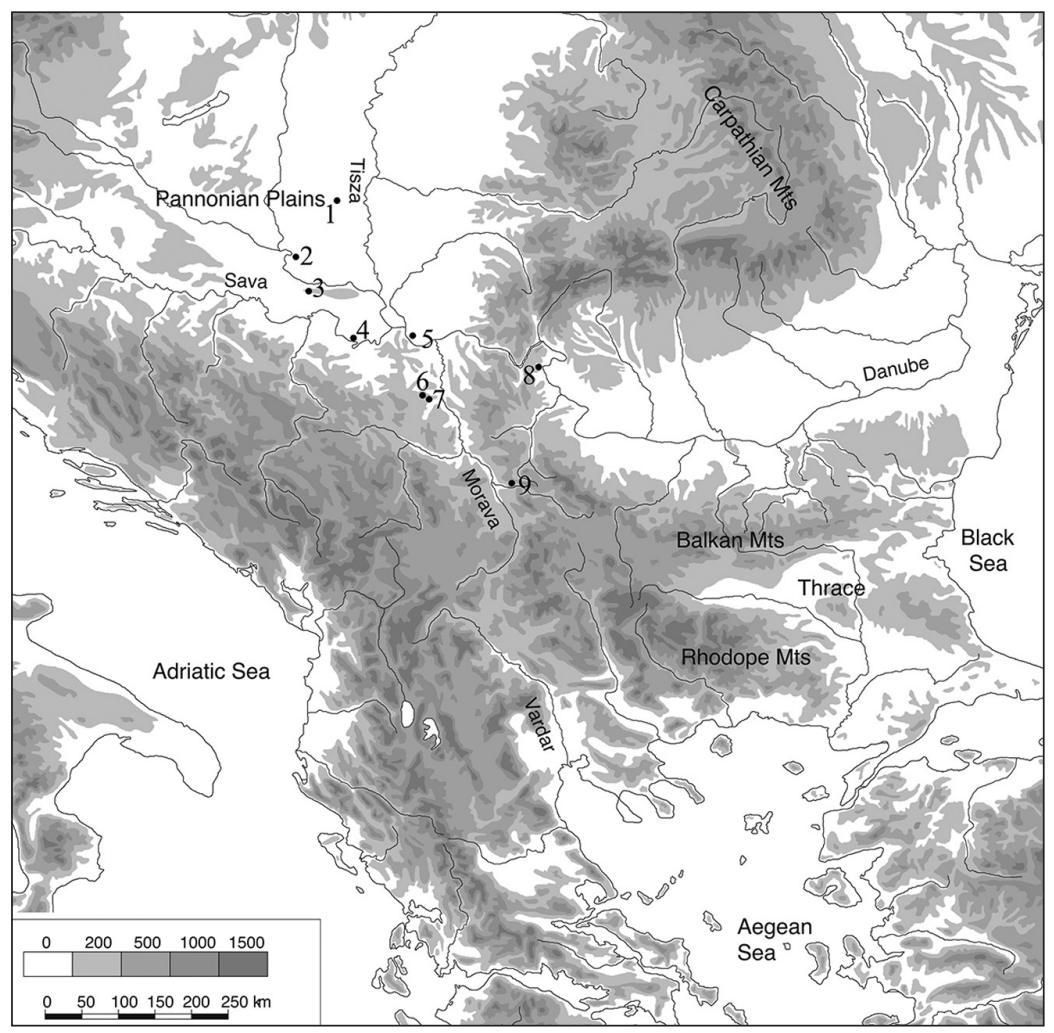

Map 1. Starčevo culture sites mentioned in the text: 1 Ludaš-Budžak, 2 Donja Branjevina, 3 Golokut-Vizić, 4 Obrě̌-Baštine, 5 Starčevo-Grad, 6 Grivac, 7 Divostin, 8 Velesnica (Ušće Kameničkog Potoka and Knjepište are located near-by) and 9 Pavlovac-Kovačke Njive. most conspicuous being the introduction of clay technology: ceramics were used for daily and storage pots, everyday artefacts such as weights, but also figurines and other cult objects (so-called altars, etc.) (e.g., Vuković 2013).

Changes in other technologies may be observed as well; lithic and osseous tools are now adapting to new materials and new tasks connected with agricultural activities, life in villages, etc. We can assume that perishable technologies changed as well (leather, textile, wood working). In the lithic industry we may note in particular the introduction and more widespread use of polished stone artefacts (axes, adzes, chisels, etc.) and ground stone artefacts (whetstones, grindstones, etc.) (Antonović 2003).

\section{Bone technology in Starčevo culture}

Osseous tools had an important role in craft production and daily activities, and also other utensils and personal ornaments were made from these raw materials. The bone industry shows certain traits that can be characterised as Mesolithic traditions, but also numerous innovations, including Near-Eastern influences. The bone industry from the following sites was included in the analysis: Donja Branjevina, Starčevo-Grad, Golokut-Vizić, Obrež-Baštine, Ludaš-Budžak, Divostin, Grivac, Tečić, Drenovac, Ušće Kameničkog Potoka, Knjepište, Velesnica, Bubanj, Pavlovac-Kovačke Njive (Vitezović 2011a; 2011c; 2012a; 2013a; 2014) (Map 1). Some of these sites were excavated in the first half of the $20^{\text {th }}$ century and not all of the faunal remains were carefully collected, so the data are not of equal quality, but these assemblages still yielded important information on the osseous industries.

\section{Choice of raw material}

Osseous raw materials used for craft production may be acquired directly, obtained either from animals killed for food, or collected (for example, shed antlers or mollusc shells), or indirectly, acquired through trade and exchange (for example, mollusc shells from distant regions). In all prehistoric 
communities, locally and directly acquired raw materials comprise the majority within osseous industries. However, this does not imply that all the available skeletal elements were unselectively used, but certain choices among available raw materials were made, directed by their physical and mechanical traits as well as by cultural preferences ( $c f$. Choyke 2013 and references therein).

The Mesolithic bone industry in the Iron Gates region is marked by the predominant use of red deer antlers (chiefly from killed animals, although shed antlers were present as well) and also diverse bones from hunted animals (auroch, red deer, roe deer), especially large long bones from large mammals used for diverse cutting and burnishing tools, followed by boar tusks and the occasional use of imported mollusc shells ( $c f$. Bačkalov 1979; Beldiman 2005; 2007; Cristiani, Borić 2012; Vitezović 2011b; precise numerical data are not available for all the sites; see Table 1 for the data from the sites at Kula and Vlasac, after Vitezović $2022 b$ and Radovanović 1996.253).

In Starčevo culture, the situation is somewhat different, as the antler ratio decreases and bones are predominant, particularly those of domestic animals prevail (for the antler and bone ratio, see Table 2). We may also observe a strict selection of both ske-
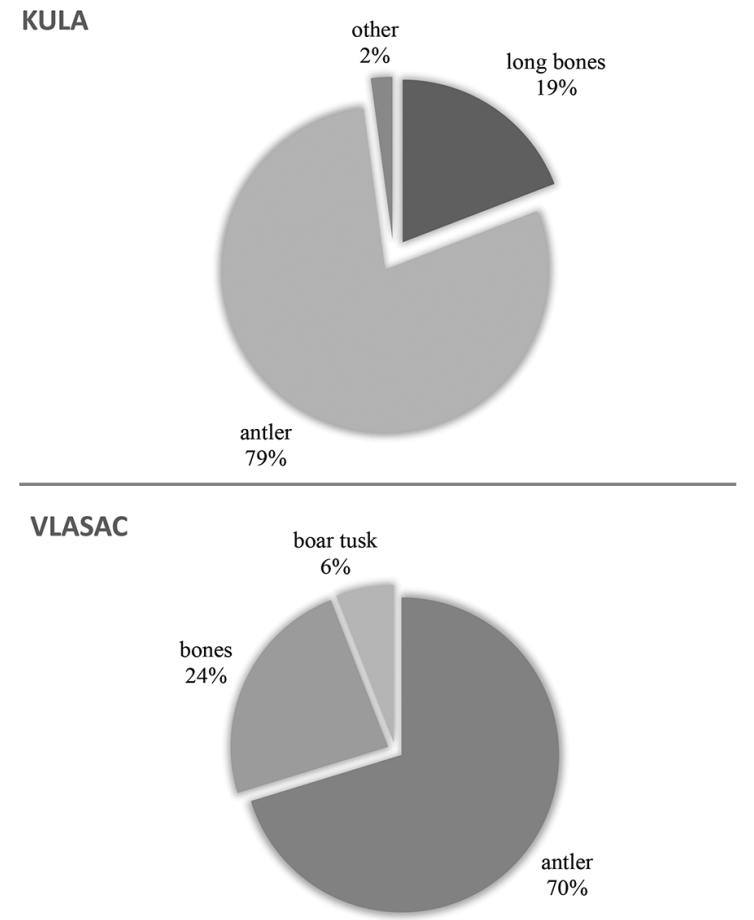

Tab. 1. The use of different osseous raw materials in the Mesolithic. Examples from the sites of Kula and Vlasac. letal elements and species. Ovicaprine bones (especially metapodia and tibiae) were best represented, followed by cattle metapodia and other ungulate long bones and ribs, mainly from domestic cattle and occasionally aurochs, red deer and roe deer (however, for ribs and some long bone segments, it is not possible to determine the species with certainty, so the percentages cannot be calculated accurately) (Vitezović 2011a; 2011c; 2013a). Antlers were mainly from red deer, with the occasional use of roe deer antlers, in most cases shed, probably collected in the relative vicinity of the settlement. There are certain differences between the Starčevo sites in the antler ratio; for example, they are abundant at some of sites, while almost completely absent at others, probably reflecting regional differences in economic aspects (cf. Vitezović 2011a; 2013a; 2014). Boar tusks (of wild and domestic pig) were used for tools and decorations, and also diverse teeth of other species, mainly wild (such as red deer canines), served as decorative items (Vitezović 2012a; 2014). Dentalium, Spondylus and Glycymeris mollusc shells were present; Dentalium beads were found only at Starčevo, while Spondylus and Glycymeris bracelets and other ornaments were found at the sites of Starčevo, Divostin and Drenovac (Vitezović 2012a).

It is interesting to note that the domestic animal bones were the most prevalent raw material at all Starčevo culture sites (however, as mentioned above, exact ratios cannot be determined), although there is a difference between the sites in the wild/domestic animal ratio. At Golokut, for example, wild animals were predominant, but exploited raw materials do not differ significantly from, for example, Donja Branjevina, where domestic fauna were dominant (cf. Blažić 1984-1985 and Blažić 2005.74-76 respectively). At Starčevo site, the ratio of wild pigs is notable (Clason 1982), although boar tusks do not stand out particularly in quantity in comparison with other sites.

This prevalence of domestic species in the raw material choices certainly points to cultural attitudes to species. An interesting case study comes from the southern Levant, where the bone tool assemblages from several subsequent periods were analysed, with the focus on the change from gazelle bones to caprinae bones (Le Dosseur 2010). During the Natufian and PPNA, gazelle bones were the predominant raw material. During the middle PPNB, an increasing number of caprines is noted in the faunal record, while the gazelle were still the preferred choice of raw material, even though goats were much more 


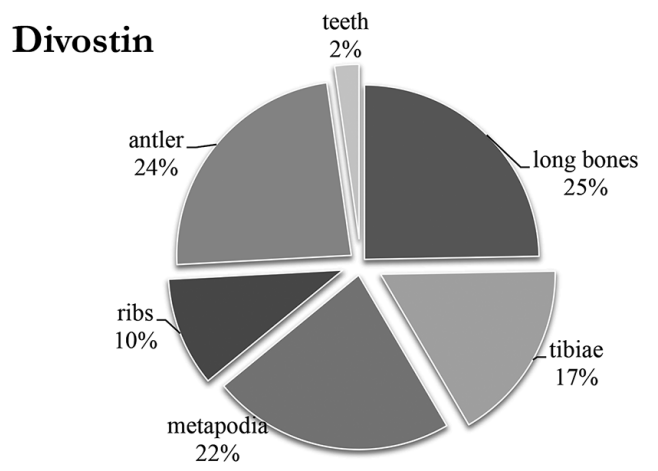

Grivac
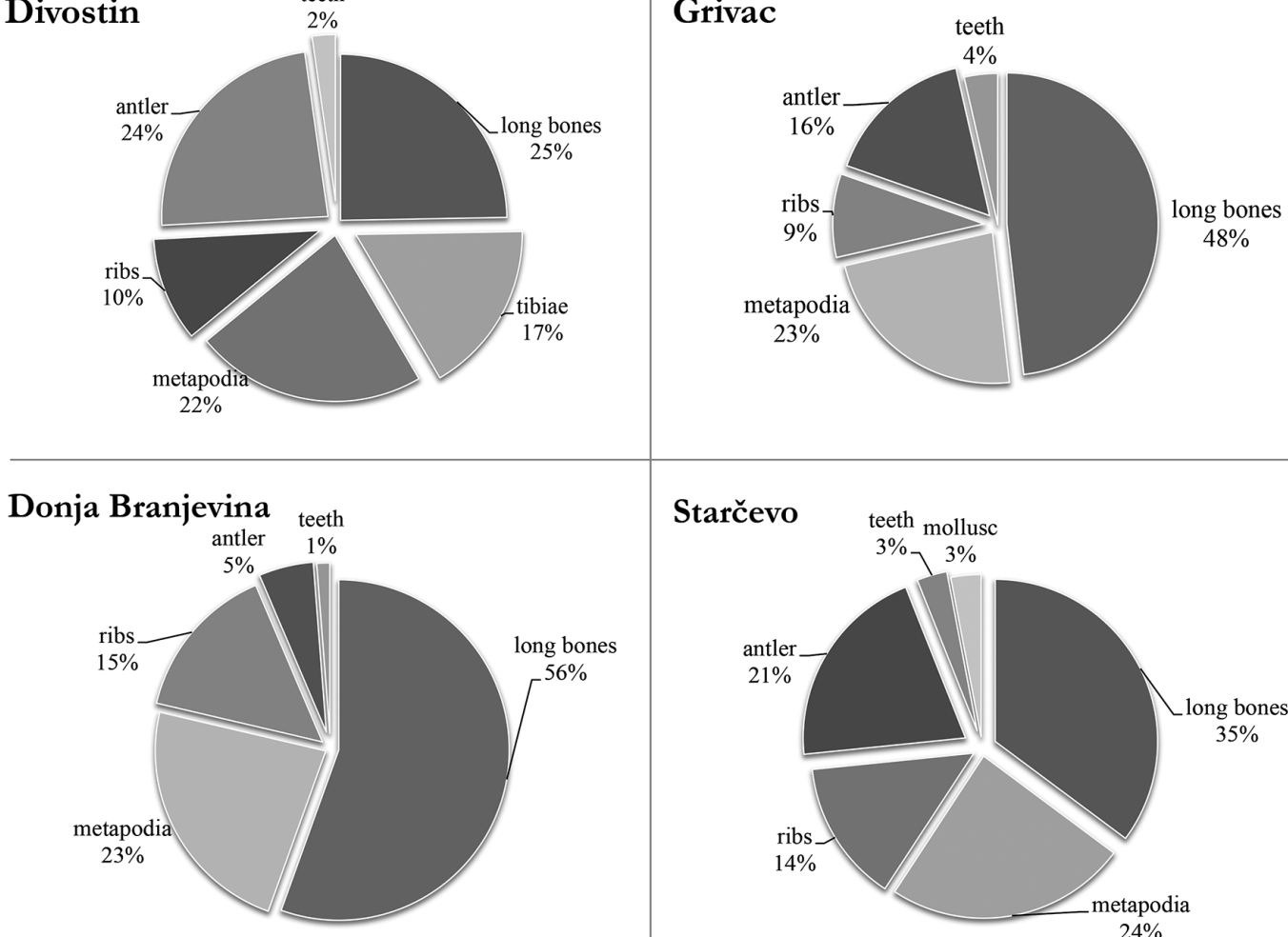

Starčevo teeth mollusc
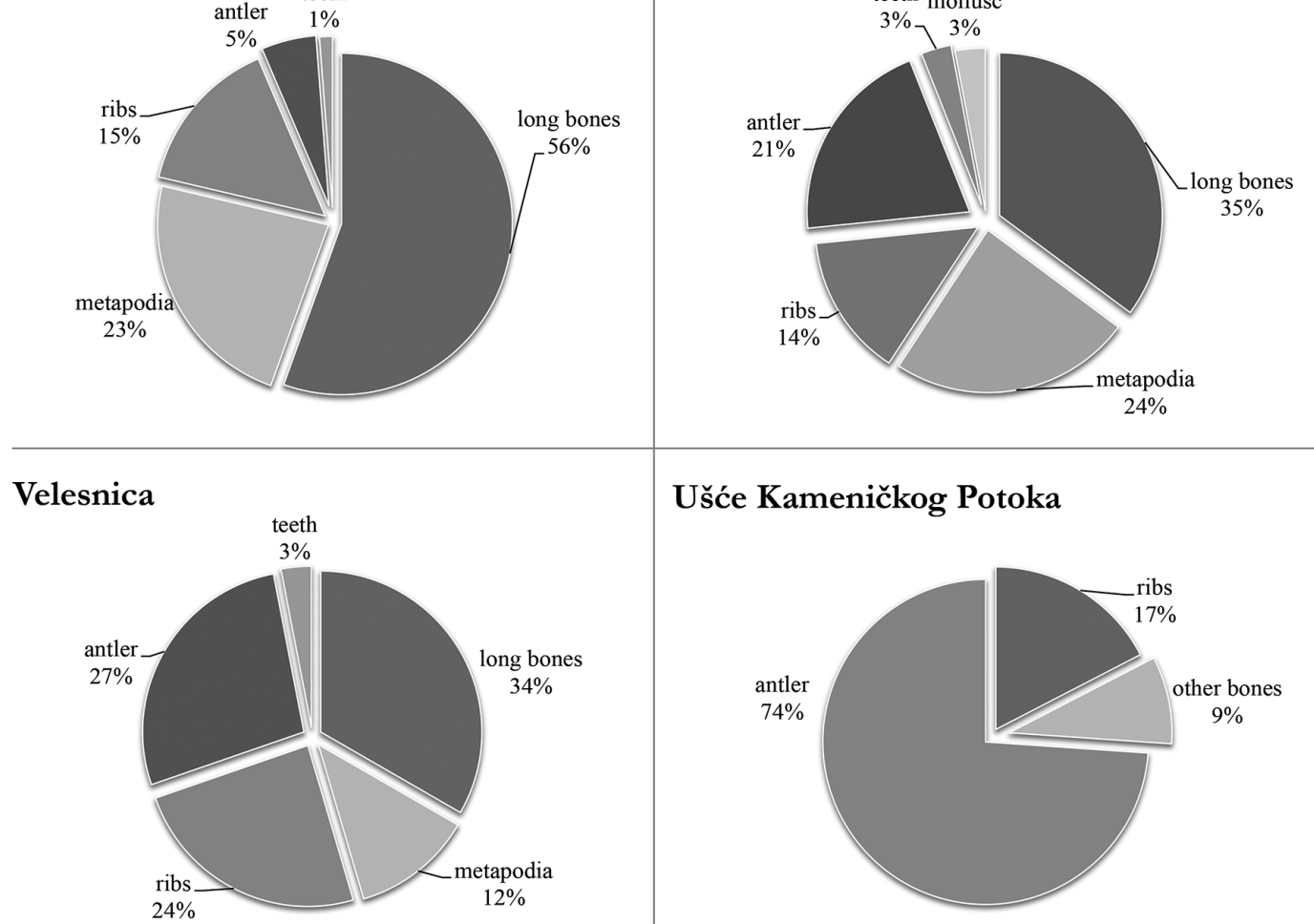

Ušće Kameničkog Potoka

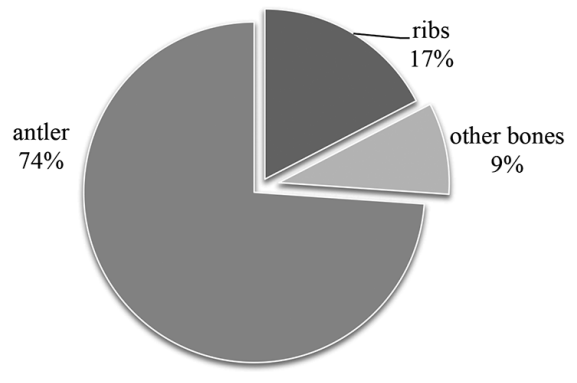

Tab. 2. The use of different osseous raw materials in the Early Neolithic. Examples from the sites of Grivac, Divostin, Starčevo, Donja Branjevina, Ušće Kameničkog Potoka and Velesnica.

numerous in the faunal assemblage. An important change occurred during late PPNB; caprine bones became the main choice of raw material, in particular those of sheep, which also increased in the faunal assemblage. Although some of this change may be purely technological (gazelle bones may be longer and thus more convenient, etc.), such a change also includes changes in attitude to the newly introduced animals. This shows that a certain time is needed for domestic animals to be fully adopted and included in all segments of life and in diverse aspects of consumption.

\section{Manufacturing techniques}

Most of the manufacturing techniques encountered within the Starčevo culture have much in common with techniques practised throughout prehistoric Europe (cf. Beldiman 2007; Sidéra 2005; Stratouli 1998, inter alii). Some of the débitage techniques for antler artefacts show certain similarities with Mesolithic technology, in methods of detaching blanks, in shaping cutting tools, etc. (cf. Vitezović 2014).

Several distinct technological features may be observed in the manufacturing process, including some technical procedures typical of the Early and Middle Neolithic in Southeast Europe.

The main innovation in Neolithic technology was the widespread use of abrasion, directly linked with the introduction and widespread use of abrasive stone tools (cf. Antonovic 2003). Most of the bone 
and antler objects were finished by abrasion; their distal ends are modelled by grinding and burnishing with diverse, coarse- and fine-grained stone tools, or entire surfaces are finely burnished and polished.

Pointed tools (awls, needles) made from small ruminant metapodials present a particularly interesting method of shaping. This tool type was widespread in Europe throughout the Neolithic period (e.g., Bačkalov 1979; Beldiman 2007; Makkay 1990; Sidéra 2005; Stratouli 1998). Three distinctive manufacturing methods were in use: (1) manufacture using abrasion only; (2) manufacture by first sawing the metapodia in half and then abrading it; and/or (3) manufacture by first abrading and then by sawing (cf. Murray 1979, Sidéra 2005) (Figs. 1, 2).
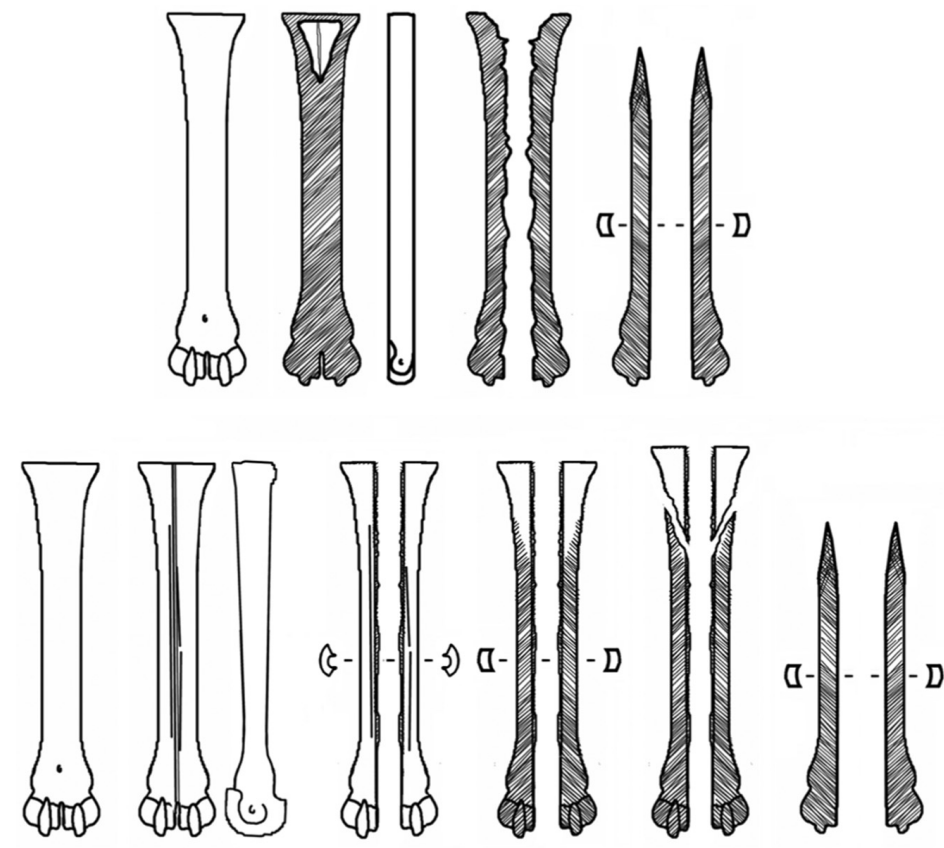

Fig. 1. Reconstruction of methods of making pointed tools from metapodial bones (after Sidéra 2005).
All three techniques for shaping were quite well represented in Starčevo-Körös-Criş culture and the Early and Middle Neolithic in the region (cf. Beldiman 2007; Beldiman, Sztancs 2011; Makkay 1990; Tóth 2012; Stratouli 1998). In the first and third method, the metapodial bone is first ground with an abrasive stone on both sides (dorsal and ventral) until it becomes flat. It may then be further shaped by abrasion only, or by a combination of cutting with a flint tool and abrasion (Figs. 1,2). This results in very thin, fine points (Fig. 3). The distal epiphysis, usually preserved at the base, may be reduced to a very small, almost flat knob or simply ground from all sides, thus obtaining a more or less regular square shape. This method allowed more precise shaping, but limited the number of artefacts which could have been fashioned from a single piece of raw material. The second method may enable a maximum of four tools from a single bone, while the results were not so fine, but more resilient, stronger awls. In later periods, methods that included abrasion as the first step disappeared, and the second technique became predominant (cf. Bačkalov 1979; Russell 1990; Vitezović 2007).

Also, the method of transversal division into segments was new; this was done by making a groove along the circumference of the bone and then the final millimetre or so of the bone was simply snapped or broken off. A groove could have been made with a flint tool, or by abrasive fibre, or a combination of the two (Fig. 4). The transversal cutting of bones, especially large and thick long bones of large mammals was quite difficult, but this method produced blanks of regular shape, which was not possible by breaking or chopping. This technique was not noted in the Mesolithic and seems to be disappearing with the Late Neolithic period in the region ( $c f$. Bačkalov 1979; Russell 1990; Vitezović 2007).

Another specific technique is the method for making large perforations. Besides the widespread method of making perforations by drilling with a flint borer (with sand added) to obtain smaller holes (5$8 \mathrm{~mm}$ in diameter), there was another method for making larger holes $(1-1.5 \mathrm{~cm}$ in diameter) with a tubular, hollow tool instead (perhaps some sort of reed tube or something similar), with an abrasive substance added (e.g., sand) (Fig. 11; Vitezović $2013 b$ ). These large perforations leave distinctive debris in the form of small circles, as discovered at several sites of the Starčevo-Körös-Criş cultural com-

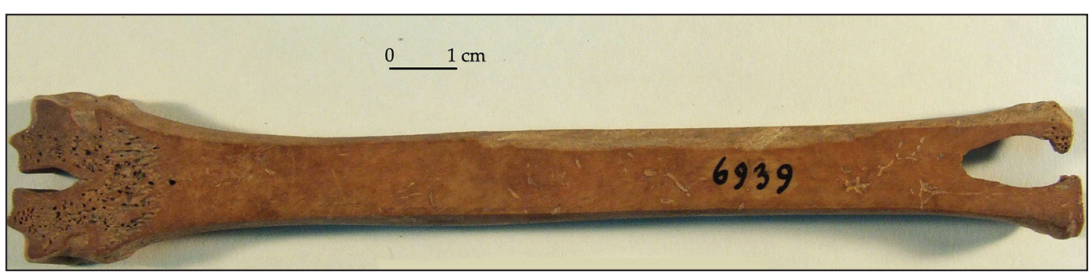

Fig. 2. Ovicaprine metapodial bone, completely ground - blank for producing pointed tools from Starčevo-Grad. 


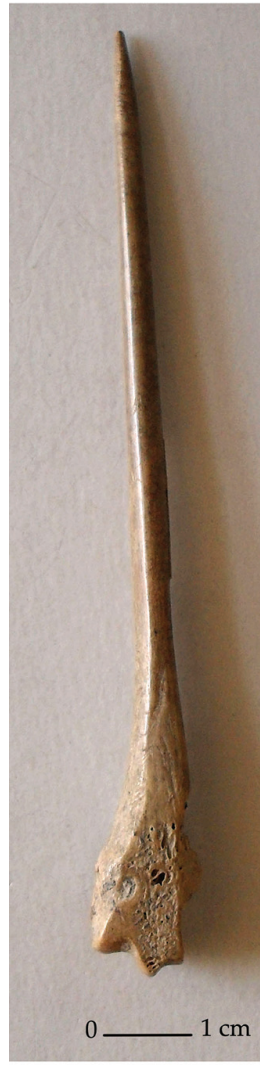

Fig. 3. Fine awls obtained only by abrasion from Donja Branjevina.
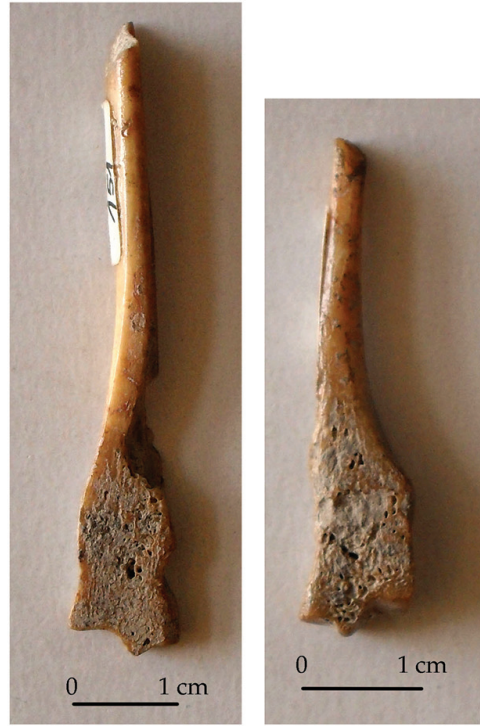

plex (cf. Beldiman, Sztancs 2011; Makkay 1990; Tóth 2012; see also Vitezović $2013 b$ and references therein).

\section{Techno-types}

Numerous tools have simple, widespread shapes that are not culturally or chronologically characteristic such as awls from longitudinally split long bones, scrapers from ribs, etc. The morphological traits of most antler tools do not differ significantly from their Mesolithic counterparts such as chisels, wedges, axes, adzes, hammers, small punching tools (cf. Vitezović 2014). In particular, retouching tools may be considered as result of much longer traditions. Also, some other tools have the same or minimally modified morphology, such as boar tusk scrapers, spatulae and other burnishing tools, etc.

Several new techno-types are introduced with the Starčevo culture. According to Isabelle Sidéra (1998), Anatolian influences, present in the osseous industries in Southeast Europe, included the presence of some or all of the following techno-types: pointed tools and tools with a cutting edge made from small ruminant tibiae, antler sickles, elaborated fishhooks, needles with perforation made by incision, buckles, crude axes, beads from bird bones, and spoons ( $c f$. also Dekker 2014; Marinelli 1995; Russell 2006; 2012).
The presence and quantity of these techno-types varies at different Starčevo culture sites; for example, at some, none were identified, while they were relatively numerous at the others (see Table 3 for details).

From Starčevo culture, only one antler sickle has been discovered, a fragmented piece from LudašBudžak (Vitezović 2014.168). Needles with perforations made by incision are virtually unknown, with only one being found at Pavlovac-Kovačke Njive ( $\mathrm{Vu}$ ković et al. 2016), while crude axes and beads from bird bones have not been encountered. Elaborated fishhooks are also rare; only a few were discovered at Donja Branjevina (Vitezović 2011a; 2011c) (Fig. 5).

Spatulae-chisels from ovicaprine tibiae were discovered at Grivac, Divostin, Rudnik near Srbica and Pavlovac-Kovačke Njive (Vitezović 2011a; Vuković et al. 2016) (Fig. 6). The largest number was noted at Divostin; however, they are not numerous and, in general, not as important as, for example, in Bulgarian Karanovo I-II culture (cf. Lang 2004).

The most important techno-types of Anatolian origin among the Starčevo bone artefacts are spatulaespoons and several decorative items. Spatulae-spoons were widespread in the Near East (cf. Dekker 2014), and are abundant throughout the entire Starčevo-Körös-Criş cultural complex ( $c f$. Beldiman 2007; Beldiman, Sztancs 2011; Makkay 1990; Nandris 1972; Tóth 2012; Vitezović 2011a; 2011c; 2013a) as well

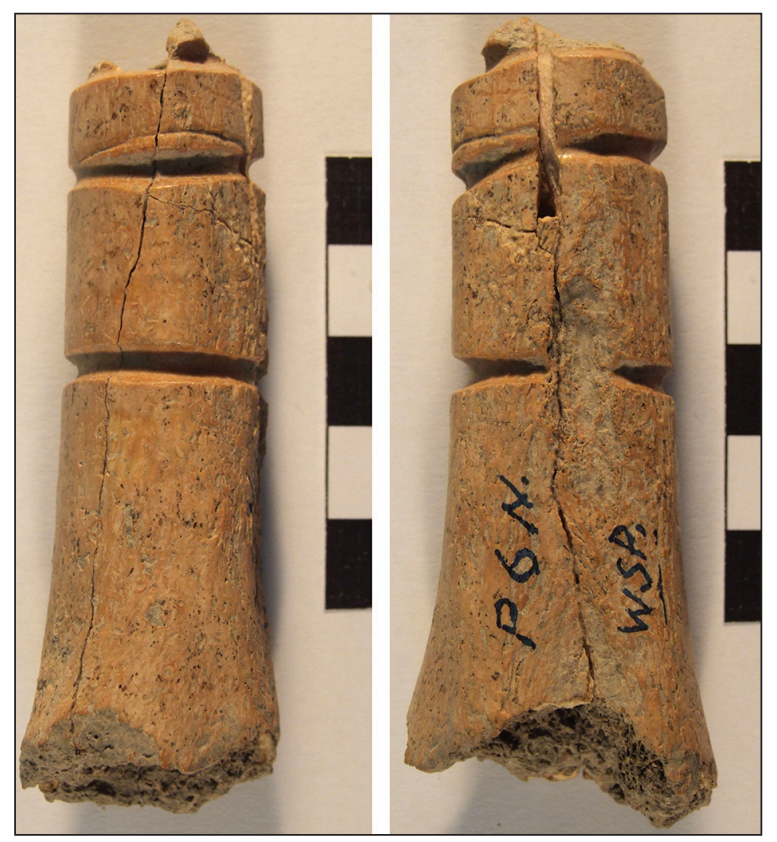

Fig. 4. Manufacture debris with traces of unfinished transversal cutting, from Starčevo-Grad. 
as within Karanovo I-II culture (cf. Lang 2004; Zidarov 2014).

Spatulae-spoons were made exclusively from large ungulate metapodial bones, probably all from Bos. Although it was suggested by John Nandris (1972) that only bones of the wild species Bos primigenius were in use, it seems that Starčevo examples were probably all from Bos taurus. Spatulae-spoons have elongated handles with cylindrical or oval cross-sections, straight or gently curved, and a bowl at the distal end, usually completely flat or slightly concave. Bowl shapes vary: they may be elongated, leaf-shaped, shorter, triangular, or, rarely, oval (Figs. 7, 8).

Zoomorphic handles, known from Anatolian sites, have not been discovered; however, it should be noted that one projectile-shaped artefact from Donja Branjevina, probably a re-worked spoon, had a zoomorphic base (Vitezović 2011c.31). Also from Donja Branjevina, one fragmented piece has a peculiar base, decorated with two rows of incisions (Vitezović 2011c.Fig. 18/2), and from Tečić may be mentioned one example with incisions on both sides on basal part of the bowl (Fig. 8). No other decorations were discovered (for example, notches, known from Anatolian sites, cf. Dekker 2014).

Spatula-spoons were produced through several stages of cutting, scraping, burnishing, polishing, etc. (cf. Nandris 1972; Sidéra 2013), and, according to the experimental work of Isabelle Sidéra (2013.174), this manufacturing technique demanded a lot of time, over 25 hours of work in total, and also a lot of skill. All these artefacts were used intensively; the bowls show high polish and shine, and at the same time, the bone is flattened, worn out and abraded from use. Edges are sometimes broken or damaged from use, and on some bowl segments it may be seen that they continued to be in use even after the

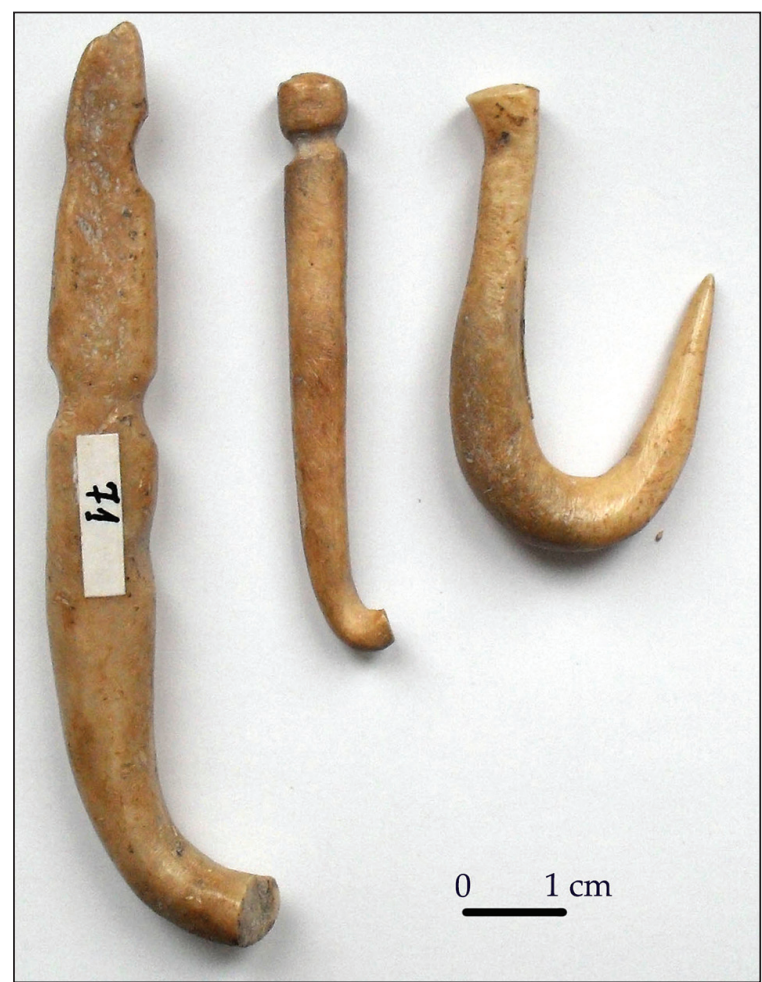

Fig. 5. Elaborated fishhooks from Donja Branjevina.

breakage. Also, a high level of polish and shine, as well as fine striations, often spread over entire surfaces, may be noted. Their function is still not clear; the intensive usewear, especially damage, was interpreted as being related to contact with either clay or stone (cf. Georgiev 1967; Nandris 1972). They may have been used on special occasions, and their original purpose may have been related to processing different plants, perhaps 'special' plants, such as medicines or spices. They might have also served as cosmetic tools ( $c f$. also Dekker 2014; Russell 2006; 2012). In Starčevo culture, they were used for a long time and often repaired, so it may be assumed that their original function was rather important (Vitezovic 2011a). Their final function was probably as

\begin{tabular}{|c|c|c|c|}
\hline $\begin{array}{r}\text { Spatu } \\
\text { ovi }\end{array}$ & $\begin{array}{l}\text { ae-chisels from } \\
\text { aprine tibiae }\end{array}$ & Spatulae-spoons & Buckles in shape of open bracelet \\
\hline Donja Branjevina & l & 42 (out of 344 total osseous artefacts) & 2 (out of 6 total decorative items) \\
\hline Starčevo-Grad & 1 & 41 (out of 250 total osseous artefacts) & 5 (out of 21 total decorative items) \\
\hline Golokut-Vizić & I & 1 (out of 39 total osseous artefacts) & 4 (out of 7 total decorative items) \\
\hline Obrež-Baštine & 1 & 3 (out of 27 total osseous artefacts ) & 2 (out of 3 total decorative items) \\
\hline Divostin & 17 & 1 (out of 96 total osseous artefacts ) & l \\
\hline Grivac & 1 & 1 (out of 58 total osseous artefacts ) & 2 (out of 6 total decorative items) \\
\hline Tešić & l & 1 (out of 4 total osseous artefacts) & l \\
\hline Bubanj & l & 1 (out of 16 total osseous artefacts ) & l \\
\hline Velesnica & 1 & 3 (out of 39 total osseous artefacts ) & l \\
\hline Ušće Kameničkog Potoka & l & / (total of 23 osseous artefacts) & l \\
\hline
\end{tabular}

Tab. 3. The presence of different tool types of Near Eastern origin at Starčevo culture sites. 


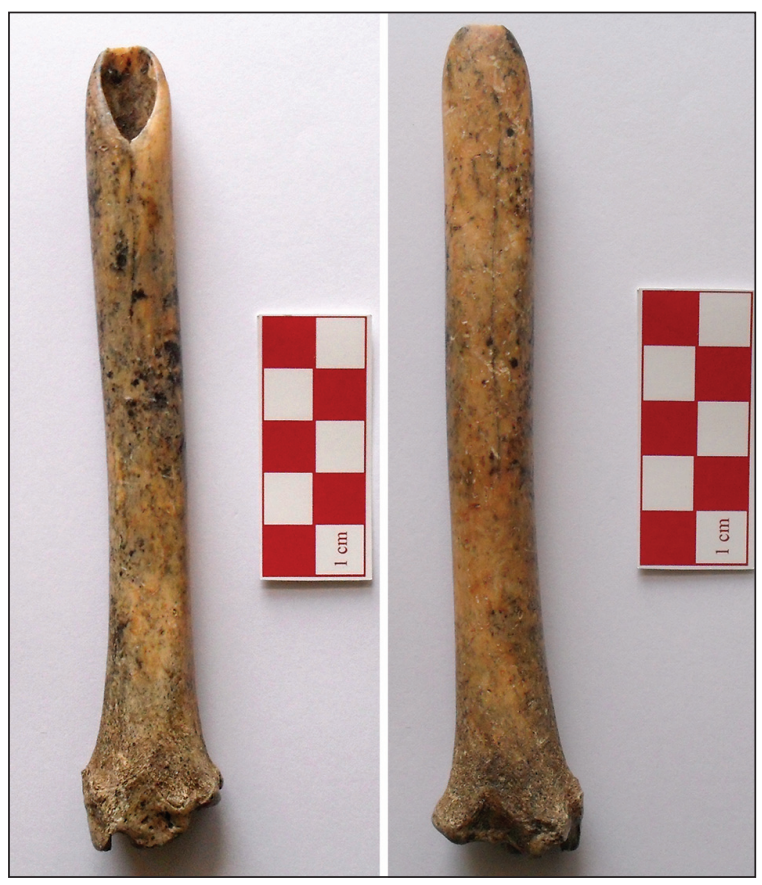

Fig. 6. Spatula-chisel from ovicaprine tibia from Pavlovac-Kovačke Njive.

some sort of burnisher, as suggested by the presence of the high level of polish and shine consistent with prolonged contact with soft organic materials, such as leather, hide and plant fibres (cf. Peltier 1986; Maigrot 2003; Legrand 2007; also cf. observations by Tóth 2012.175).

Projectile points comprise a very interesting group of artefacts, among which three sub-types may be
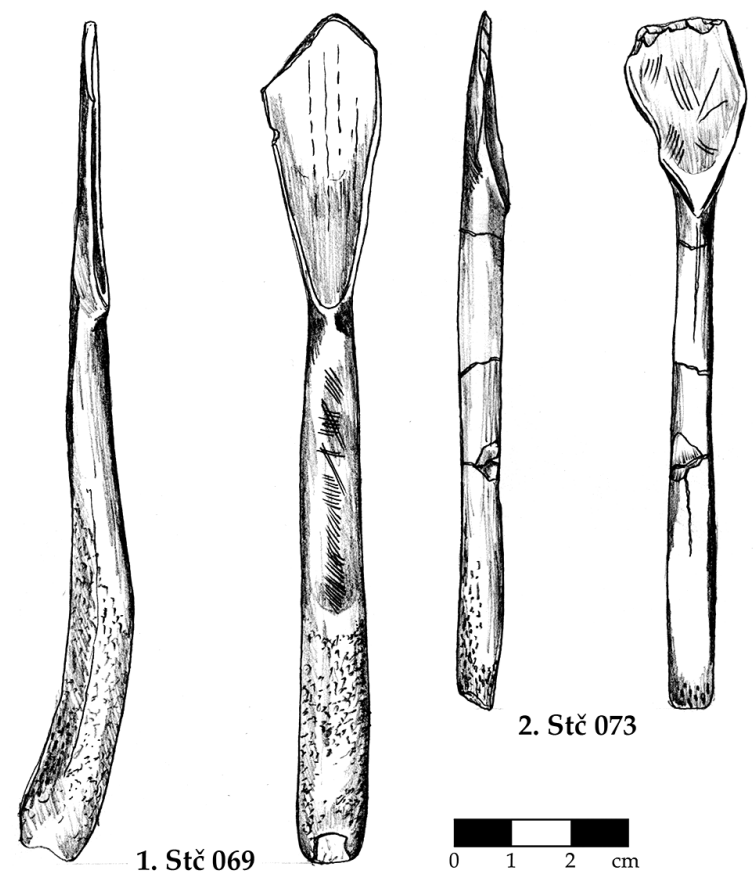

Fig. 7. Spatula-spoons from Starčevo-Grad. outlined: two of these show technological and morphological connections with Mesolithic ones, but the third subtype is technologically connected with spatulae-spoons; furthermore, some of these are reworked broken spoons (Fig. 9) (Vitezović 2012b).

The new artefact types also include several decorative items. This includes buckles in the form of an open bracelet, all made from long bones of considerable size, from large ungulates, probably Bos. Bones were cut transversally by making a groove with abrasive fibre, and then by cutting the bone with a flint tool. All these objects have carefully shaped heads made by cutting with a flint tool, and all the surfaces were carefully polished with some fine-grained stone. However, their original shape is unknown - whether they were in the form of a halfcircle or almost full circle - as they are all broken in the middle. This breakage is probably due to use; these peculiar artefacts may have been used as some sort of belt buckle or clasp for clothing (Fig. 10). Similar to those, probably a morphological variation,

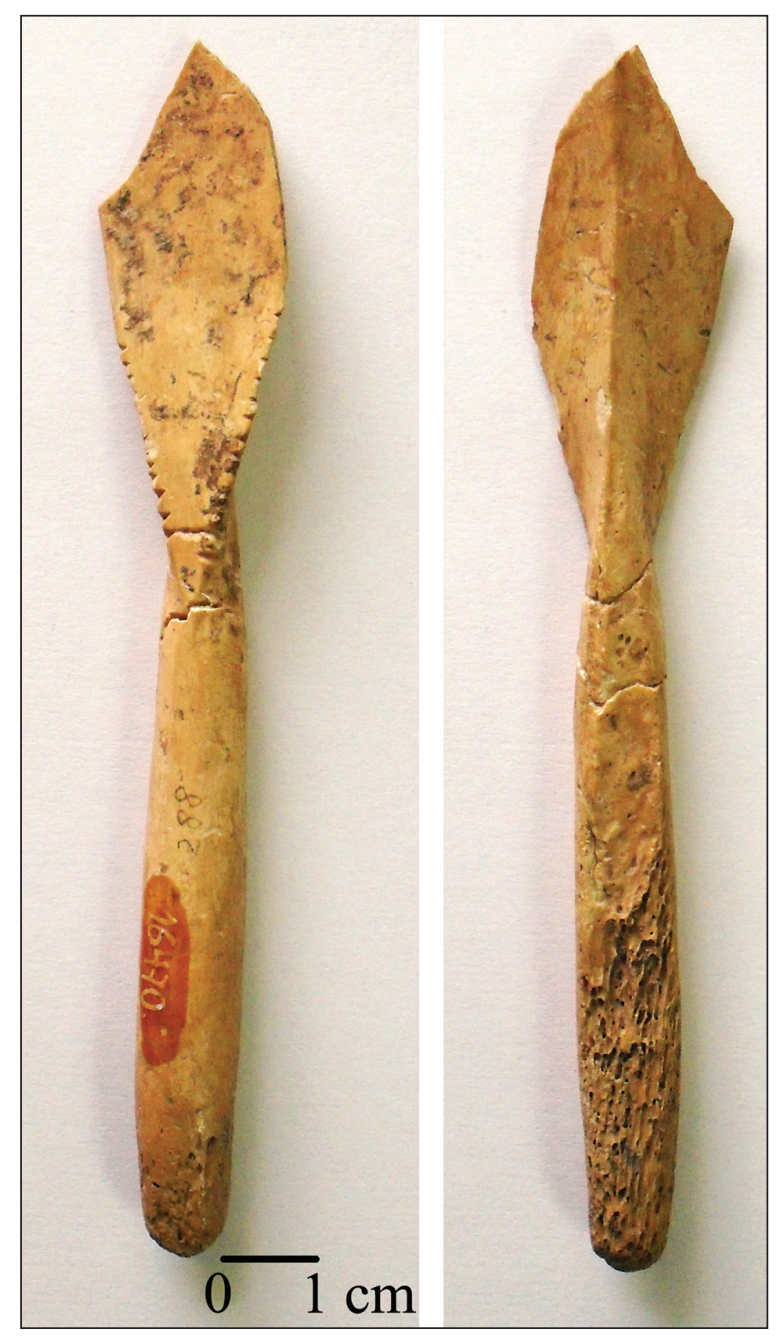

Fig. 8. Spatula-spoon from Tečić. 
are buckles in the form of buttons with a rounded head made from a piece cut out from a long bone, finely polished.

Among the region- and culture-specific decorative items rings, disks and rectangular plates with large holes may also be included, all of similar morphology with slight variations, obtained by use of the above-mentioned specific techniques of transversal cutting or making large perforations (Fig. 11). They were made either by transversally cutting large long bones (ring-shaped pieces) or from diverse flat pieces of bones, mainly from diaphyses of large long bones, by cutting, burnishing and polishing and by making large holes with a hollow tool (discs and rectangular perforated plates) (Vitezović 2013b).

There is one more trait that shows Near Eastern influences - tools with serrated (denticulated or notched) edges. Different artefact types may have one or more edges with dents or notches that are either purely decorative or may have certain function. Two artefacts from Divostin of unknown function (Fig. 12), as well as several diverse artefacts, spoons, awls, burnishers, have certain parts with wide Ushaped notches or dense incisions that create wavy or denticulated edges. The level of use wear differs in them and it is difficult to determine their function. They may have been used for making decorations on other, soft materials (such as textile); however, no experimental work has been conducted yet. Similar serrated artefacts are encountered in other Pre-Neolithic and Neolithic cultures in the Near East and in Southeast Europe. Several morphologically similar artefacts were discovered at the site of Tell Mureybet with traces of use that cover the range from modest polish up to completely used dents. Several hypotheses on use were offered; however, the experimental work conducted by Rozalia Christidou was inconclusive (Stordeur, Christidou 2008.522-528). As for our examples, a small number of finds and large variations in form further complicate the interpretation of the function and must await future new finds and experimental work.

The most important difference in the use of osseous raw materials between the Mesolithic and Starčevo populations in the Balkans is in their symbolic use. In the Mesolithic, decorations may occasionally be found on non-worked skele-

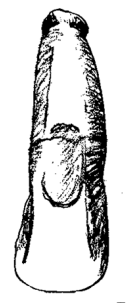

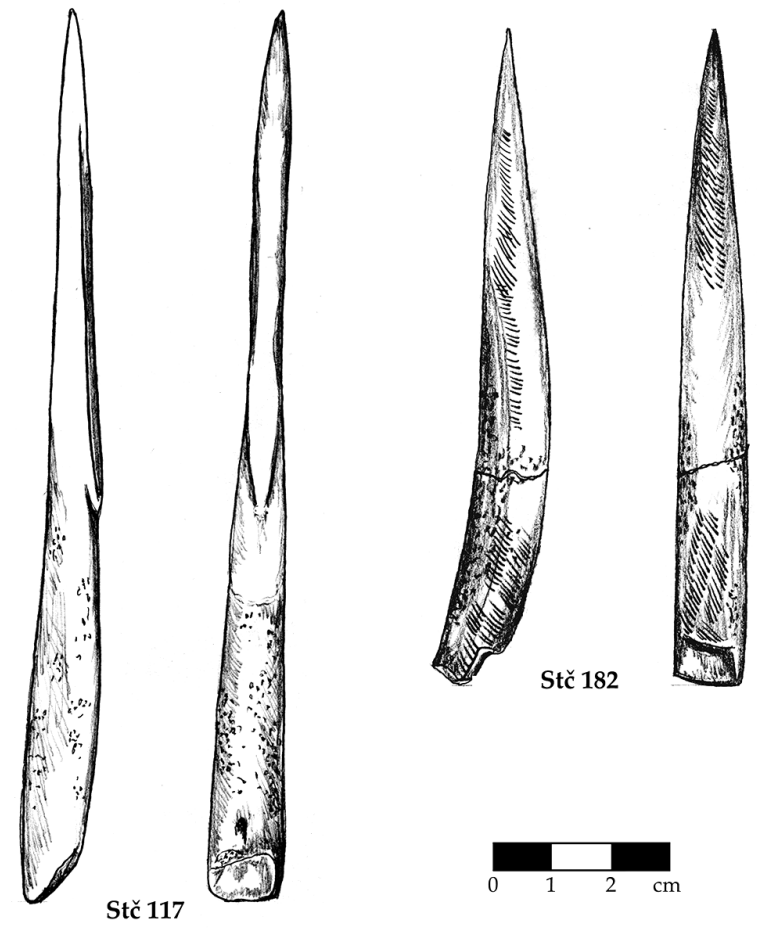

Fig. 9. Projectile points manufactured as spatulaspoons from Starčevo-Grad.

tal elements (such as antler segments, such as a roe deer antler from Vlasac, Srejović, Letica 1978.T LXX) or finished and used tools (such as a possible retouching tool from Vlasac, Srejović, Letica 1978.T. LXXVI, and more examples in Boroneant 1970; 2000; Radovanovic 1996). These were mainly incised decorations that formed net, zig-zag or wavy motifs. In Starčevo culture, decoration has not been discovered on any bone artefacts. However, in both cultures, osseous raw materials were widely used for decoration (Bačkalov 1979; Vitezović 2012a), as in
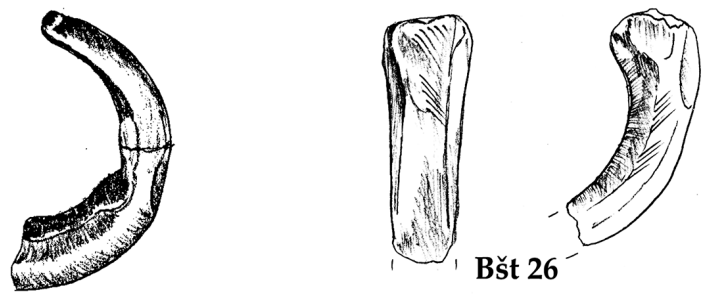

Stč 017

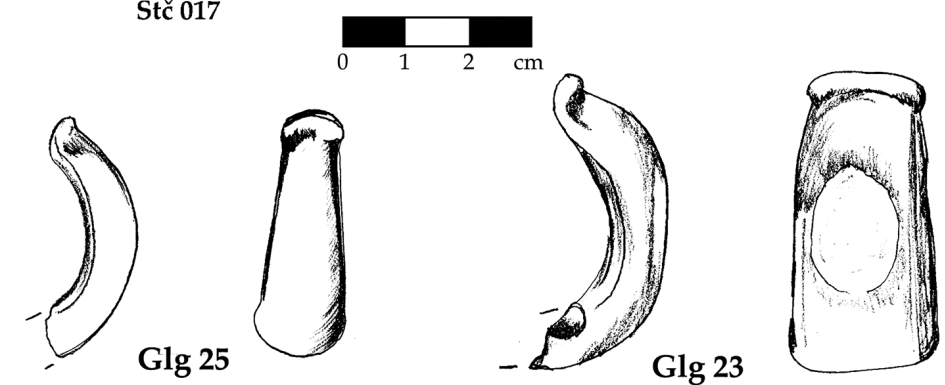

Fig. 10. Buckles in a shape of an open bracelet from Golokut, Baštine, and Starčevo-Grad. 

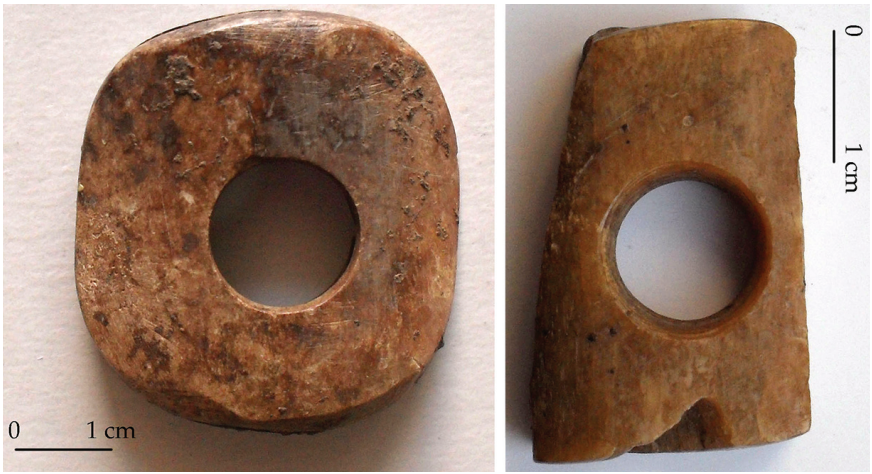

Fig. 11. Decorative rectangular plates with large holes from Grivac.

numerous other prehistoric cultures across Europe and the Near East (cf. Taborin 2004).

\section{Discussion and conclusion}

The bone industry in the Starčevo culture was a welldeveloped and important craft, and osseous raw materials were important for producing diverse items, everyday tools and decorative objects. The osseous industry was also closely connected with other technological aspects of Starčevo crafts, displaying innovations connected with the introduction of the Neolithic way of life.

The acquisition and management of raw materials changed significantly as the economy changed. Sheep,

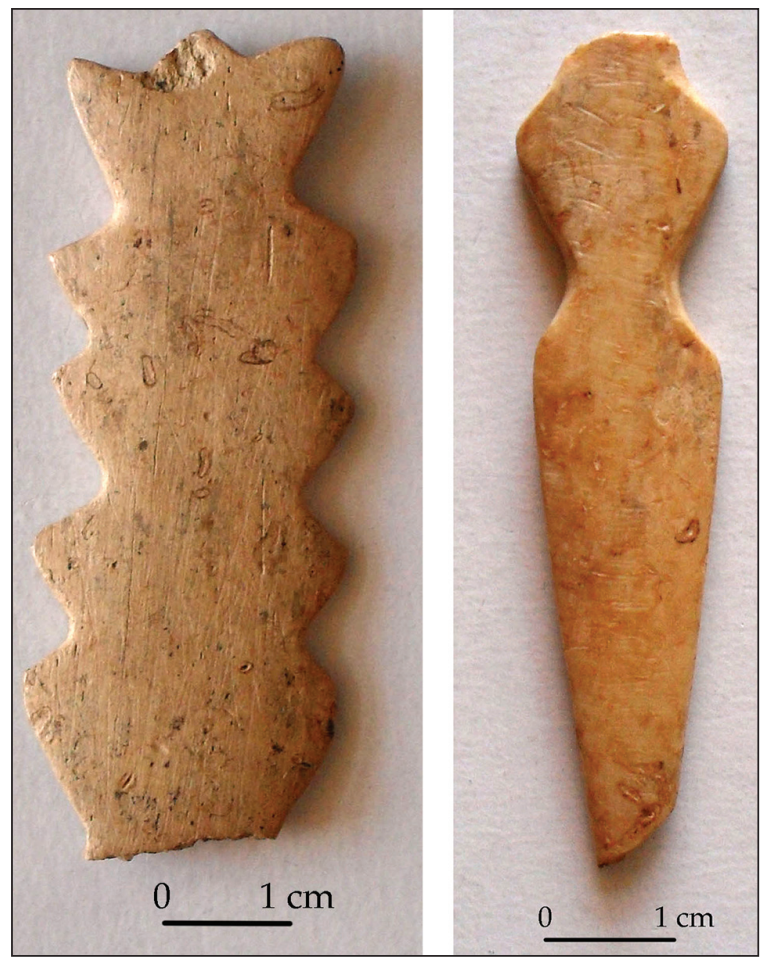

Fig. 12. Artefacts with notches from Divostin. goat and cattle bones now prevail, showing that domestic animals had been fully adopted and accepted in all aspects of the economy and consumption, and were not only acceptable, but preferable raw material for most daily tools. The predominant acquisition of shed antlers demonstrates close knowledge of the environment, as the red deer tend to shed their antlers in the same place every year (cf. Clutton-Brock 1984).

Manufacturing techniques also show innovations connected with modifications in other technologies. The most important change is the adoption and widespread use of ground stone tools for several finishing steps, burnishing and polishing. Furthermore, the application of this new method created technical procedures that may be considered as cultural-chronological markers.

Mesolithic traditions are present to a relatively low extent, and the question of their origin remains open. Some of Mesolithic traits may be considered characteristic of several Mesolithic populations, not only those from the Iron gates region; therefore, the question of contact with the Mesolithic Iron Gates population and its nature remains open.

The increased quantity of fine- and medium-sized pointed tools (needles, awls) (see Tab. 4), including

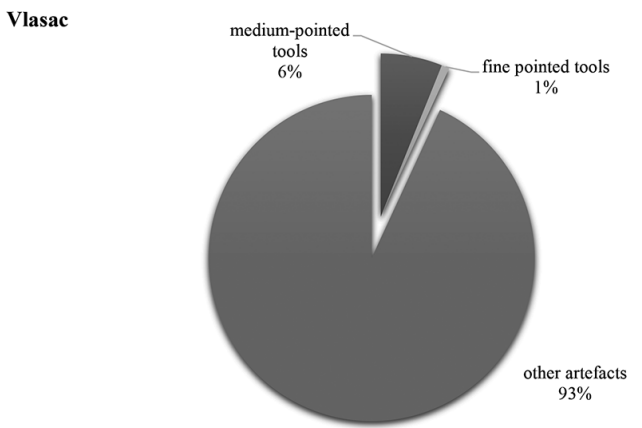

Starčevo

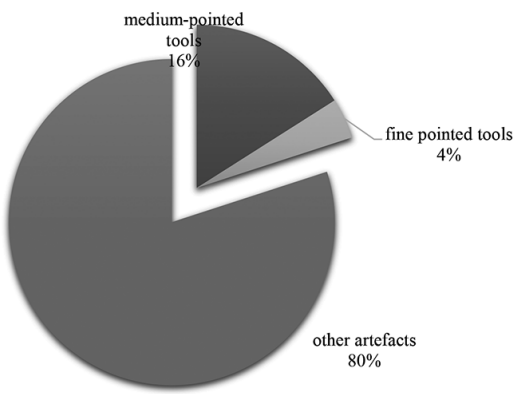

Tab. 4. The ratio of fine and medium pointed tools versus other artefacts. Examples from the sites of Vlasac (Mesolithic) and Starčevo (Early Neolithic). 
very thin awls obtained through abrasion only, perhaps point to an increased production of perishable technologies, i.e. in processing plant fibres, leather, and hides.

Techno-types of Near-Eastern origin were present in most of the bone industries in Southeast Europe, but with significant differences in distribution, importance and technological modifications. In her analysis of new elements of Near-Eastern origin in Eastern Balkan bone industries, Sidéra (1998) noted that the style of production changes rapidly from one site to another. In the case of the Starčevo culture bone industry, we may note that only some of the 'package' of Anatolian influences was adopted; furthermore, some of what was adopted had already been partially altered (such as the forms and functions of spatulaespoons). It is particularly interesting to note that decorative items, probably used to display status and/or prestige, show important Near-eastern influences, but again, in a somewhat modified way.

The most interesting examples are the projectile points, where a symbiosis of tradition and innovation may be observed: subtypes with Mesolithic forms and the introduction of a new subtype closely connected with the most important Near-Eastern artefact type, the spatula-spoon.

The most important difference between the Mesolithic (and earlier Palaeolithic traditions) is in the cul- tural attitude to osseous raw materials: they are no longer used for figural representations or decorations, while the new material, clay, is now preferred for diverse figural presentations and for objects of possible cultic function. Osseous raw materials are now predominantly used for daily tools, but retained their role for producing personal ornaments ( $c f$. $V i$ tezović 2012a).

The Starčevo culture osseous industry shows an interesting mix, preserving some techno-typological traits connected with Mesolithic tradition while introducing new techno-types, mainly of Near-Eastern origin, but somewhat altered during the process of adoption into the new cultural milieu. Technological traditions and innovations are never straightforward, or simply transferred from one culture to another, but must pass through a process of adoption and adaptation to the new economic, social and cultural environment.

This paper is the result of work on the projects 'Archaeology of Serbia: cultural identity, integrational factors, technological processes and the role of the central Balkans in the development of the European prehistory', no. OI 177020, and 'Bioarchaeology of ancient Europe: humans, animals and plants in the prehistory of Serbia', no. III 47001, funded by the Ministry for Education and Science.

\section{References}

Antonović D. 2003. Neolitska industrija glačanog kamena u Srbiji. Arheološki institut. Beograd.

2006. Stone tools from Lepenski Vir. Arheološki institut. Beograd.

Bačkalov A. 1979. Predmeti od kosti $i$ roga u predneolitu i neolitu Srbije. Savez Arheoloških društava Jugoslavije. Beograd.

Bartosiewicz L., Bonsall C. and Şişu V. 2008. Sturgeon fishing along the Middle and Lower Danube. In C. Bonsall, V. Boroneant and I. Radovanović (eds.), The Iron Gates in Prehistory. New perspectives. British Archaeological Report IS 1893. Archaeopress. Oxford: 39-54.

Beldiman C., Sztancs D.-M. 2011. Technology of skeletal materials of the Starčevo-Criş Culture in Romania. In S. A. Luca, C. Suciu (eds.), The First Neolithic Sites in Central/
South-East European Transect, vol II: Early Neolithic (Starčevo-Criş) Sites on the Territory of Romania. British Archaeological Reports IS 2188. Archaeopress. Oxford: $57-70$.

Beldiman C. 2005. Paleotechnology of antler working in the Mesolithic of the Iron Gates, Romania. In H. Luik, A. Choyke, C. Batey and L. Lõugas (eds.), From Hooves to Horns, from Mollusc to Mammoth - Manufacture and Use of Bone Artefacts from Prehistoric Times to the Present. Proceedings of the $4^{\text {th }}$ Meeting of the ICAZ Worked Bone Research Group at Tallinn, 26th-31st of August 2003. Muinasaja teadus 15. Tallinn: 33-46.

2007. Industria materiilor dure animale $\hat{\imath}$ preistoria României. Resurse naturale, comunităti umane și tehnologie din paleoliticul superior până în neoliticul timpuriu. Asociaţia Română de Arheologie. Studii de Preistorie, Supplementum 2. Editura Pro Universitaria. București. 
Blažić S. 1984-5. Prilog poznavanju ostataka faune sa arheološkog lokaliteta "Golokut". Rad Vojvođanskih muzeja 29: 33-36.

2005. The faunal assemblage. In S. Karmanski, Donja Branjevina: A Neolithic settlement near Deronje in the Vojvodina (Serbia). Società per la preistoria e protoistoria della regione Friuli-Venezia Giulia. Quaderno 10. Trieste: 74-76.

Bökönyi S. 1978. The vertebrate fauna of Vlasac. In M. Garašanin (ed.), Vlasac. A Mesolithic Settlement in the Iron Gates. Volume II. Geology - Biology - Anthropology. Serbian Academy of Sciences and Arts. Belgrade: 35-65.

Bonsall C 2008. The Mesolithic of the Iron Gates. In G. Bailey, P. Spikins (eds.), Mesolithic Europe. Cambridge University Press. Cambridge: 238-279.

Borić D. 2002. Seasons, life cycles and memory in the Danube Gorges, $c$. 10000-5500 BC. Unpublihed PhD thesis. Department of Archaeology. University of Cambridge. Cambridge.

Borić D., Dimitrijević V. 2007. Apsolutna hronologija i stratigrafija Lepenskog Vira (Absolute chronology and stratigraphy of Lepenski Vir). Starinar LVII: 9-55.

Boroneanţ V. 1970. La période épipaléolithique sur la rive roumaine des Portes de Fer du Danube. Prähistorische Zeitschrift 45(1): 1-25.

2000. Paléolithique supérieur et épipaléolithique dans la zone des Portes de Fer. Editura Silex. București.

Cauvin J. 1997. Naissance des divinités, naissance de l'agriculture. Le Centre National de la Recherche Scientifique. Paris.

Choyke A. 2013. Hidden agendas: ancient raw material choice for worked osseous objects in central Europe and beyond. In A. Choyke, S. O'Connor (eds.), From These Bare Bones: Raw Materials and the Study of Worked Osseous Objects. Oxbow. Oxford: 1-11.

Clason A. 1982. Padina and Starčevo: Game, Fish and Cattle. Palaeohistoria XXII: 141-173.

Clutton-Brock J. 1984. Excavations at Grimes Graves, Norfolk, 1972-1976. Fascicule 1: Neolithic antler picks from Grimes Graves, Norfolk, and Durrington Walls, Wiltshire: a biometrical analysis. British Museum Press. London.

Cristiani E., Borić D. 2012. 8500-Year-old Late Mesolithic garment embroidery from Vlasac (Serbia): Technological, use-wear and residue analyses. Journal of Archaeological Science 39: 3450-3469.
Dekker K. 2014. What tools can tell The Bone Tools of Barcin Höyük. Unpublished MA thesis. Free University of Amsterdam. Amsterdam.

Dimitrijević V. 2008. Lepenski Vir animal bones: what was left in the houses? In C. Bonsall, V. Boroneant and I. Radovanović (eds.), The Iron Gates in Prehistory. New perspectives. British Archaeological Reports IS 1893. Archaeopress. Oxford: 117-130.

Dinu A. 2010 Mesolithic fish and fishermen of the lower Danube (Iron Gates). Documenta Praehistorica 37: 299310 .

Filipović D., Obradović Đ. 2013. Archaeobotany at Neolithic sites in Serbia: a critical overview of the methods and results. In N. Miladinović-Radmilović, S. Vitezović (eds.), Bioarheologija na Balkanu. Bilans i perspektive. Radovi bioarheološke sekcije Srpskog arheološkog društva. Srpsko arheološko društvo and Blago Sirmiuma. Beograd, Sremska Mitrovica: 25-55.

Georgiev G. 1967. Beiträge zur Erfoschung des Neolithikums und der Bronzezeit in Südbulgarien. Archaeologia Austriaca 42: 90-144.

Greenfield H. 2008 Faunal assemblages from the Early Neolithic of the central Balkans: methodological issues in the reconstruction of subsistence and land us. In C. Bonsall, V. Boroneant and I. Radovanović (eds.), The Iron Gates in Prehistory. New perspectives. British Archaeological Reports IS 1893. Archaeopress. Oxford: 205-226.

Hayden B. 1998. Practical and prestige technologies: The evolution of material systems. Journal of archaeological method and theory 5(1): 1-55.

Hodder I. 1990. The domestication of Europe. Basil Blackwell. Oxford.

Killick D. 2004. Social Constructionist Approaches to the Study of Technology. World Archaeology 36(4): 571-578.

Lang F. 2004. Chronologisch sensible Knochengerättypen am Beispiel Tell Karanovo. In V. Nikolov, K. Bačvarov and P. Kalchev (eds.), Prehistoric Thrace. Institute of Archaeology with Museum - BAS and Regional Museum of History Stara Zagora. Sofia - Stara Zagora: 359-369.

Le Dosseur G. 2010. The Neolithisation in Southern Levant: Impact of animal herding on the exploitation of bone materials, from retinence to adoption of domestic herds. In A. Legrand-Pineau, I. Sidéra, N. Buc, E. David and V. Scheinsohn (eds.), Ancient and Modern Bone Artefacts from America to Russia. Cultural, technological and functional signature. British Archaeological Reports IS 2136. Archaeopress. 0xford: 17-30. 
Legrand A. 2007. Fabrication et utilisation de l'outillage en matières osseuses du Néolithique de Chypre: Khirokitia et Cap Andreas-Kastros. Archaeopress. Oxford.

Lemonnier P. 1986. The study of material culture today: toward an anthropology of technical systems. Journal of Anthropological Archaeology 5: 147-186.

1992. Elements for and anthropology of technology. Anthropological Papers. University of Michigan - Museum of Anthropology. Ann Arbor.

1993. Introduction. In P. Lemonnier (ed.), Technological choices: transformation in material cultures since the Neolithic. Routdledge. London: 1-35.

Maigrot Y. 2003. Étude technologique et fonctionnelle de l'outillage en matières dures animales La station 4 de Chalain (Néolithique final, Jura, France). Unpublished $\mathrm{PhD}$ thesis. Université de Paris I. Paris.

Makkay J. 1990. Knochen, Geweih und Eberzahngegenstände. Communicationes Archaeologiae Hungaricae 38: $23-58$

Marinelli M. 1995. The bone artifacts of Ilipinar. In J. Roodenberg (ed.), The Ilipinar Excavation I. Five Seasons of Fieldwork in Nothwestern Anatolia, 1987-91. Nederlands Historisch-Archaeologisch Instituut te Istanbul. Leiden: 121-142.

Murray C. 1979. Les techniques de débitage de métapodes de petits ruminants à Auvernier-Port. In H. Camps-Fabrer (ed.), Industrie de l'os et bois de cervidé durant le néolithique et âge des métaux. Première réunion du groupe de travail no. 3 sur l'industrie de l'os préhistorique. Le Centre National de la Recherche Scientifique. Paris: $27-35$.

Nandris J. 1972. Bos primigenius and the bone spoon. Bulletin of the Institute of Archaeology 10: 63-82.

Peltier A. 1986. Étude expérimentale des surfaces osseuses façonnées et utilisées. Bulletin de la Société Préhistorique Française 83(1): 5-7.

Pfaffenberger B. 1992. Social anthropology of technology. Annual review of anthropology 21: 491-516.

Radovanović I. 1981. Ranoholocenska kremena industrija sa lokaliteta Padina u Đerdapu. Arheološki institute. Beograd.

1996. The Iron Gates Mesolithic. International Monographs in Prehistory. Ann Arbor.

Russell N. 1990. The Bone Tools. In R. Tringham, D. Krstić (eds.), Selevac. A Neolithic village in Yugoslavia. Monu- menta Archaeologica. University of California, Los Angeles. Los Angeles: 521-548.

2006. Çatalhöyük worked bone. In I. Hodder (ed.), Çatalhöyük perspectives: reports from the 1995-99 seasons. British institute at Ankara. McDonald Institute Monographs. Cambridge: 339-367.

2012. Worked bone from the BACH area. In R. E. Tringham, M. Stevanović (eds.), BACH Area Reports from Catalhöyük. The Cotsen Institute of Archaeology Press. Los Angeles: 347-359.

Sidéra I. 1998. Nouveaux éléments d'origine ProcheOrientale dans le Néolithique ancient balkanique: analyse de l'industrie osseuse. In M. Otte (ed.), Préhistoire d'Anatolie. Genèse de deux mondes. Études et recherches archéologiques de l'Université de Liège. Liège: 215-239.

2005. Technical data, typological data: a comparison. In H. Luik, A. Choyke, C. Batey and L. Lõugas (eds.), From Hooves to Horns, from Mollusc to Mammoth - Manufacture and Use of Bone Artefacts from Prehistoric Times to the Present. Proceedings of the $4^{\text {th }}$ Meeting of the ICAZ Worked Bone Research Group at Tallinn, 26th-31st of August 2003. Muinasaja teadus 15. Tallinn: 81-90.

2013. Manufacturing bone tools: The Example of Kovačevo. In N. Miladinović-Radmilović, S. Vitezović (eds.), Bioarheologija na Balkanu. Bilans i perspektive. Radovi bioarheološke sekcije Srpskog arheološkog društva. Srpsko arheološko društvo and Blago Sirmiuma. Beograd, Sremska Mitrovica: 173-178.

Sinclair A. 1995. The Technique as a Symbol in Late Glacial Europe. World Archaeology 27(1): 50-62.

1998. The value of tasks in the late Upper Palaeolithic. In D. Bailey (ed.), Archaeology of value. Essays on Prestige and the Process of Valuation. British Archaeological Reports IS 730. Archaeopress. Oxford: 10-16.

Srejović D., Letica Z. 1978. Vlasac. Mezolitsko naselje u Đerdapu. Tom I, Arheologija (Vlasac. A Mesolithic settlement in the Iron Gates. Vol I, Archaeology). Serbian academy of sciences and arts, monographies DXII. Beograd.

Stordeur D., Christidou R. 2008. L'industrie de l'os. In J. J. Ibáñez (ed.), Le site néolithique de Tell Mureybet (Syrie du Nord). En hommage à Jacques Cauvin. British Archaeological Reports IS 1843. Archaeopress. Oxford: 439-538.

Stratouli G. 1998. Knochenartefakte aus dem Neolithikum und Chalkolithikum Nordgriechenlands. Rudolf Habelt. Bonn.

Taborin Y. 2004. Langage sans parole. La parure aux temps préhistoriques. La maison des roches. Paris. 
Tóth Zs. 2012. Bone, antler and tusk tools of the Early Neolithic Körös culture. In A. Anders, Zs. Siklósi (eds.), Central/South-East European Transect, volume III: The Körös Culture in Eastern Hungary. British Archaeological Reports IS 2334. Archaeopress. 0xford: 171-178.

Vitezović S. 2007. Koštana industrija u neolitu srednjeg Pomoravlja. Unpublished MA thesis. Faculty of Philosophy. Beograd University. Beograd.

2011a. Koštana industrija u starijem i srednjem neolitu centralnog Balkana. Unpublished $\mathrm{PhD}$ thesis. Faculty of Philosophy. Belgrade University. Belgrade.

2011b. The Mesolithic bone industry from Kula, eastern Serbia. Before Farming 2011(3): 1-21.

2011c. Early and Middle Neolithic bone industry in northern Serbia. Acta Archaeologica Carpathica XLVI: 19-60.

2012a. The White Beauty - Starčevo culture jewellery. Documenta Praehistorica 39: 91-203.

2012b. Koštani projektili sa lokalitetaStarčevo-Grad (Osseous projectiles from the site Starčevo-Grad). Glasnik Srpskog arheološkog društva 28: 233-246.

2013a. Bone industry from Starčevo-Grad. Technology and typology. In F. Lang (ed.), The Sound of Bones. Proceedings of the $8^{\text {th }}$ Meeting of the ICAZ Worked Bone Research Group in Salzburg 2011. Archäoplus (Schriften zur Archäologie und Archäometrie an der Paris Lodron-Universität Salzburg, 5. Salzburg: 263-276.

2013b. Bone manufacturing in the Neolithic: the problems of reconstructing the chaîne opératoire and iden- tifying workshops. Archeometriai Múhely/Archaeometry Workshop 2013/3: 201-208.

2014. Antlers as raw material in the Starčevo culture. In S. Vitezović, D. Antonović (eds.), Archaeotechnology: studying technology from prehistory to the Middle Ages. Srpsko arheološko društvo. Beograd: 151-176.

Vuković J. 2013. Starčevački žrtvenici sa lokaliteta Pavlovac-Čukar: nova pitanja u arheologiji neolita (Starčevo altars from the site of Pavlovac-Čukar: New questions in Neolithic Archaeology). Glasnik Srpskog arheološkog društva 29: 7-21.

Vuković, J., Vitezović, S. and Milanović D. 2016. PavlovacKovačke Njive - Neolithic layer. In S. Perić, A. Bulatović (eds.), Archaeological investigations along the route of highway E-75 (2011-2014). Institute of Archaeology. Belgrade: $167-204$.

Wake T. 1999. Exploitation of tradition: bone tool production and use at Colony Ross, California. In M.-A. Dobres, C. R. Hoffman (eds.), The Social Dynamics of Technology: practice, politics and world views. Smithsonian Institution Press. Washington - London: 186-208.

Whittle A., Bartosiewicz L., Borić D., Pettit P. and Richards M. 2002. In the beginning: new radiocarbon dates for the Early Neolithic in northern Serbia and south-east Hungary. Antaeus 25: 63-117.

Zidarov P. 2014. Knochen- und Geweihgeräte: Traditionen und Praktiken im Alltag der Einwohner von Ovčarovo-Gorata. In R. Krauss (ed.), Ovcarovo-Gorata. Eine frühneolithische Siedlung in Nordostbulgarien. Archäologie in Eurasien 29. Deutsches Archäologisches Institut. Habelt. Bonn: 250-270. 
